\title{
A CADAVERIC STUDY OF LENGTH OF TRACHEA IN NEPALESE POPULATION OF VARIOUS AGE GROUPS
}

\author{
Nitasha Sharma ${ }^{1}$, G.A Khan ${ }^{2}$, Ruku Pandit ${ }^{3}$
}

\section{ABSTRACT}

\section{INTRODUCTION}

The trachea is centrally located membranocartilaginous unpaired hollow organ extending downwards as a continuation of the larynx. The study of the semorphometric variations is of profound clinical importance as it may help the clinicians to understand the etiology of several pulmonary diseases and the surgeons to deal with resection and reconstruction of the tracheobronchial tree. This knowledge is also helpful for smooth conduction of some maneuvers like endotracheal intubation and bronchoscopic procedures.

\section{MATERIALS \& METHODS:}

A study of length of human trachea was undertaken in the Department of Anatomy, College of Medical Science Teaching Hospital, Bharatpur, Nepal from april 2012 to December 2013. Twenty nine specimens were collected out of which, sixteen were male and thirteen were female. The specimens were grouped into five age groups for both sexes. The length of trachea, was measured and, standard error (SE), standard deviation(SD) and test of significance were calculated using independent sample ' $t$ ' test and multiple comparison test.

\section{RESULTS:}

The length of trachea, there was a rapid increase in length from 0-15 years group to 16-25 years group in both the sexes. Thereafter it exhibited very insignificant variations from 26-40 and 41-55 years group in both sexes. From 41-55 years age group to $>55$ years age group there was a slight increase in tracheal length in both sexes.

\section{CONCLUSION:}

The length of trachea varies with age and the results observed are comparatively less than written in standard books from foreign authors, hence racial difference plays a key role in the length of trachea. Furthermore, we suggest more research is required in this field from our regional area.

KEYWORDS: Morphometry, trachea, principal bronchi, cadaveric study

1. Dr. Nitasha Sharma, Lecturer, Dept. of Anatomy, UCMS

2. Dr. Gulam Anwar Khan, Asst. Professor, Dept. of Anatomy, CMS

3. Dr. Ruku Pandit, Asst. Professor, Dept of Anatomy, COMS

\author{
For correspondence: \\ Dr. Nitasha Sharma, \\ Lecturer, \\ Department of Anatomy, \\ Universal College of Medical Sciences \\ Bhairahawa, Nepal \\ Email: sharmanitasha@hotmail.com
}




\section{INTRODUCTION :}

The trachea is centrally located membranocartilaginous unpaired hollow organ extending downwards as a continuation of the larynx $x^{1}$. Its length is $10-12 \mathrm{~cm}$ long. Trachea extends from the lower border of the cricoid cartilage opposite C6 vertebra up to the upper border of T5 vertebra where it ends by dividing into right and left principal bronchi supplying the right and left lungs respectively ${ }^{2}$.

The length of trachea varies with age $^{3}$. Beside pure anthropometry, Anatomical knowledge about the length of trachea is essential for anaesthetists for selecting anatomically designed cuff for endotracheal intubation and bronchoscopic procedure ${ }^{4}$. Apart from that the study of these morphometric variations and relationship with age is of profound clinical importance as it may help the clinicians to understand the etiology and prognosis of several pulmonary diseases ${ }^{5}$.

With the above factors in limelight, the present study was taken up to measure the length, as no literature is available regarding these data amongst Nepalese population

\section{MATERIALS AND METHODS:}

The present study was conducted in the dissection hall of Department of Anatomy, College of Medical Sciences Teaching Hospital, Bharatpur, Nepal from april 2012 to December 2013.

a) Procurement of specimens (study materials):-

1. Fourteen specimens of healthy human trachea and right and left principal bronchi of different age groups of both sexes were dissected out from relatively fresh and properly embalmed unclaimed cadavers.

2. Fifteen specimens of healthy human trachea and right and left principal bronchi of different age groups of both sexes were procured from the mortuary of Bharatpur Hospital with due consent from concerned authority.

b) Sample size:-

Twenty nine specimens were studied in the present study. Fourteen specimens were dissected out from cadavers, out of which nine were from male and five from female.Fifteen specimens were collected from mortuary of Bharatpur hospital which included seven male and eight female specimens.

c) Study design:-

The present study was conducted in five different age groups in both sexes. $0-15$ years, $16-25$ years, $26-40$ years, $41-55$ years and $>55$ years. d) Morphometric study:-

1. The length of trachea from (lower border of cricoid cartilage to the point of the tracheal bifurcation) and the length of the right and left principal bronchi (from the angle of tracheal bifurcation to the point of its dividing into secondary bronchi) were recorded in centimeter scale.

e) Documentation:-

1. Photographic documentation of composite specimens were taken.

2. All the measurements were recorded in a tabulated manner age wise (the different age groups in the present study will be: $0-15$ years, $16-25$ years, $26-40$ years, $41-55$ years and 55 years and above) in both sexes.

f) Statistical analysis:-

For the measurements, the standard error, standard deviation statistical analysis and test of significance was calculated using independent sample $t^{\prime}$ test with the help of 'SPSS' software version 15.0 and recorded in a tabular form.

\section{OBSERVATIONAND RESULTS:}

The numbers of specimens studied in the five age groups were as follows:-

Table No.1. Number of specimens studied in different age groups.

\begin{tabular}{|c|c|c|c|}
\hline $\begin{array}{c}\text { Age groups } \\
\text { (in years) }\end{array}$ & $\begin{array}{c}\text { Total No. of } \\
\text { specimens }\end{array}$ & $\begin{array}{c}\text { No. of specimens } \\
\text { dissected from } \\
\text { cadavers }\end{array}$ & $\begin{array}{c}\text { No. of specimens } \\
\text { procured from } \\
\text { autopsy cases }\end{array}$ \\
\hline $0-15$ & 4 & 1 & 3 \\
\hline $16-25$ & 6 & 2 & 4 \\
\hline $26-40$ & 7 & 4 & 3 \\
\hline $41-55$ & 8 & 5 & 3 \\
\hline$>55$ & 4 & 2 & 2 \\
\hline
\end{tabular}

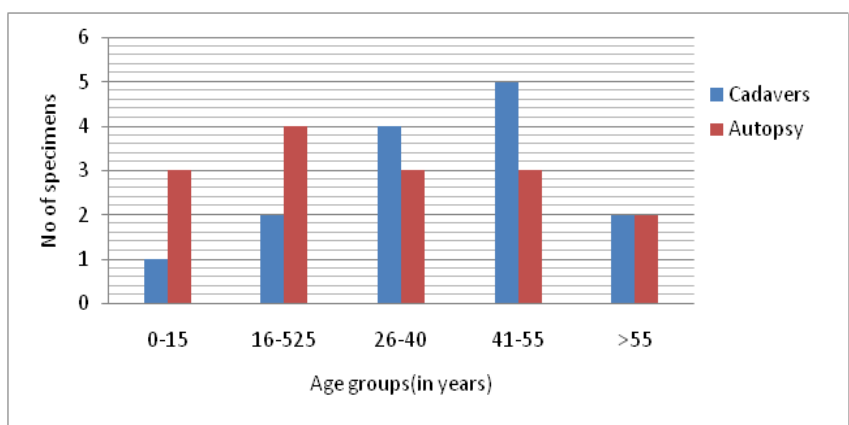

Fig1: Bar diagram showing number of specimens procured from cadavers and autopsy in different age groups. 
Table No.2. Showing sex distribution in each age group

\begin{tabular}{|c|c|c|c|}
\hline $\begin{array}{c}\text { Age groups } \\
\text { (in years) }\end{array}$ & $\begin{array}{c}\text { Total number of } \\
\text { specimens }\end{array}$ & Male Specimens & Female Specimens \\
\hline $0-15$ & 4 & 2 & 2 \\
\hline $16-25$ & 6 & 3 & 3 \\
\hline $26-40$ & 7 & 4 & 3 \\
\hline $41-55$ & 8 & 5 & 3 \\
\hline$>55$ & 4 & 2 & 2 \\
\hline
\end{tabular}

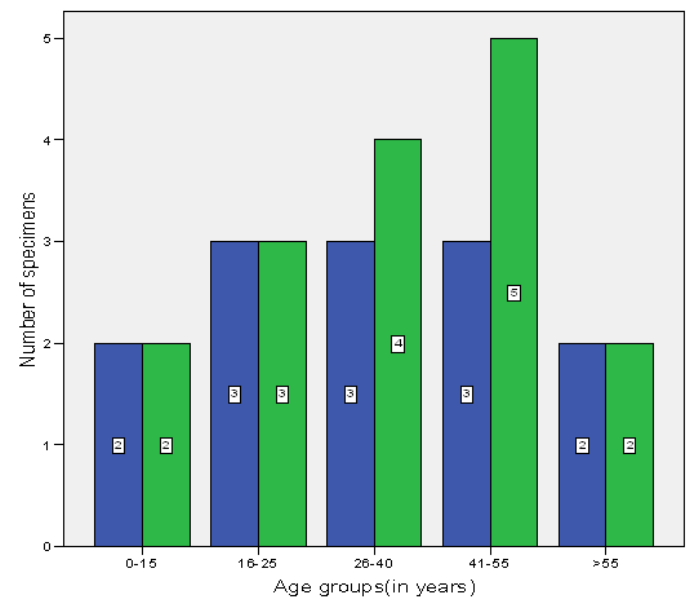

Figure 2 Bar diagram showing sex distribution in each age group.

Table No.3. Measurement of length of trachea in different age groups in male and female.

\begin{tabular}{|c|c|c|c|c|}
\hline $\begin{array}{l}\text { Age Groups } \\
\text { (in years) }\end{array}$ & $\begin{array}{c}\text { Age } \\
\text { (in years) }\end{array}$ & $\begin{array}{l}\text { Specimen No. } \\
\text { (Sp.No.) }\end{array}$ & Sex & $\begin{array}{c}\text { Length } \\
\text { (cm) }\end{array}$ \\
\hline \multirow{4}{*}{$0-15$} & 13 & 1 & $\mathrm{M}$ & 10.0 \\
\hline & 15 & 2 & $\mathrm{M}$ & 9.7 \\
\hline & 9 & 3 & $F$ & 7.0 \\
\hline & 12 & 4 & $\mathrm{~F}$ & 7.5 \\
\hline \multirow{6}{*}{$16-25$} & 22 & 5 & $\mathrm{M}$ & 11.0 \\
\hline & 18 & 6 & $\mathrm{M}$ & 10.9 \\
\hline & 24 & 7 & $\mathrm{M}$ & 10.8 \\
\hline & 20 & 8 & $F$ & 9.9 \\
\hline & 22 & 9 & $F$ & 10.0 \\
\hline & 19 & 10 & $F$ & 9.8 \\
\hline \multirow{7}{*}{$26-40$} & 27 & 11 & $\mathrm{M}$ & 10.5 \\
\hline & 38 & 12 & $\mathrm{M}$ & 10.8 \\
\hline & 35 & 13 & $\mathrm{M}$ & 10.4 \\
\hline & 28 & 14 & $\mathrm{M}$ & 10.5 \\
\hline & 39 & 15 & $\mathrm{~F}$ & 10.0 \\
\hline & 29 & 16 & $\mathrm{~F}$ & 10.1 \\
\hline & 33 & 17 & $F$ & 10.1 \\
\hline \multirow{8}{*}{$41-55$} & 50 & 18 & $\mathrm{M}$ & 9.9 \\
\hline & 48 & 19 & M & 10.1 \\
\hline & 55 & 20 & $\mathrm{M}$ & 10.0 \\
\hline & 54 & 21 & M & 10.1 \\
\hline & 53 & 22 & $\mathrm{M}$ & 9.8 \\
\hline & 43 & 23 & $F$ & 10.1 \\
\hline & 45 & 24 & $F$ & 10.0 \\
\hline & 52 & 25 & $F$ & 9.9 \\
\hline \multirow{4}{*}{$>55$} & 65 & 26 & $\mathrm{M}$ & 11.2 \\
\hline & 58 & 27 & M & 11.1 \\
\hline & 65 & 28 & $F$ & 11.0 \\
\hline & 60 & 29 & $\mathrm{~F}$ & 10.1 \\
\hline
\end{tabular}

Table No.4. Average length of trachea in male and female.

\begin{tabular}{|c|c|}
\hline Sex & Average length of trachea \\
\hline Male & $10.4 \mathrm{~cm}$ \\
\hline Female & $9.6 \mathrm{~cm}$ \\
\hline
\end{tabular}

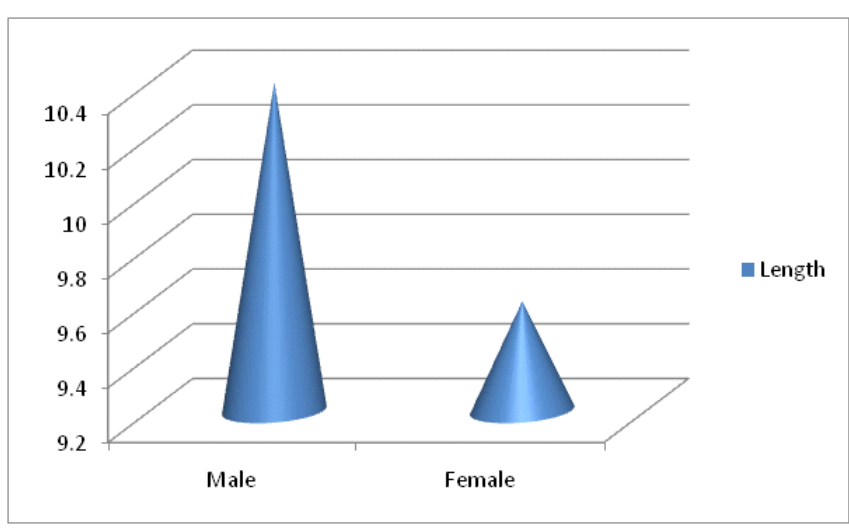

Fig 3: Cone diagram showing average length of trachea in male and female.

Table No.5. Measurement of mean length of trachea in different age groups in male and female

\begin{tabular}{|c|c|c|}
\hline \multirow{2}{*}{ Sex } & $\begin{array}{c}\text { Age groups } \\
\text { (in years) }\end{array}$ & $\begin{array}{c}\text { Mean length } \\
(\mathrm{cm})\end{array}$ \\
\hline \multirow{3}{*}{ M } & $0-15$ & 9.85 \\
\cline { 2 - 3 } A & $16-25$ & 10.90 \\
\cline { 2 - 3 } L & $26-40$ & 10.55 \\
\cline { 2 - 3 } E & $41-55$ & 9.98 \\
\cline { 2 - 3 } F & $>55$ & 11.15 \\
\cline { 2 - 3 } E & $0-15$ & 7.25 \\
\cline { 2 - 3 } A & $16-25$ & 9.90 \\
\cline { 2 - 3 } L & $26-40$ & 10.07 \\
\cline { 2 - 3 } E & $41-55$ & 10.66 \\
\cline { 2 - 3 } & $>55$ & 10.55 \\
\hline
\end{tabular}

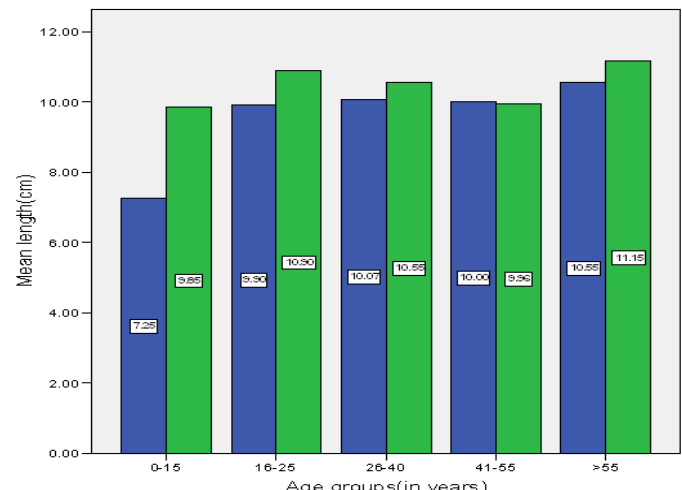

sex
昌

Figure 4. Diagram showing mean length of trachea in different age groups in male and female. 
Table No.6. Statistical constants of mean length of trachea in different age groups in male and female including test of significance using independent sample test.

\begin{tabular}{|c|c|c|c|c|c|c|}
\hline Sex & $\begin{array}{c}\text { Age } \\
\text { groups } \\
\text { (in years) }\end{array}$ & $\begin{array}{c}\text { Mean } \\
\text { length } \\
\text { (cm) }\end{array}$ & $\begin{array}{c}\text { Standard } \\
\text { Deviation } \\
\text { (SD) }\end{array}$ & $\begin{array}{c}\text { Standard } \\
\text { Error } \\
\text { (SE) }\end{array}$ & p value & $\begin{array}{c}\text { Significance } \\
\text { (sig) }\end{array}$ \\
\hline M & $0-15$ & 9.85 & 0.21 & 0.15 & 0.012 & isg \\
\cline { 2 - 7 } $\mathrm{A}$ & $16-25$ & 10.90 & 0.10 & 0.05 & 0.000 & hsg \\
\cline { 2 - 7 } $\mathrm{L}$ & $26-40$ & 10.55 & 0.17 & 0.86 & 0.006 & isg \\
\cline { 2 - 7 } $\mathrm{E}$ & $41-55$ & 9.98 & 0.13 & 0.05 & 0.829 & isg \\
\cline { 2 - 7 } & $>55$ & 11.15 & 0.63 & 0.05 & 0.316 & isg \\
\hline $\mathrm{F}$ & $0-15$ & 7.25 & 0.35 & 0.25 & 0.012 & isg \\
\cline { 2 - 7 } $\mathrm{E}$ & $16-25$ & 9.90 & 0.10 & 0.05 & 0.000 & hsg \\
\cline { 2 - 7 } $\mathrm{M}$ & $26-40$ & 10.07 & 0.57 & 0.03 & 0.006 & isg \\
\cline { 2 - 7 } $\mathrm{A}$ & $41-55$ & 10.00 & 0.10 & 0.05 & 0.702 & isg \\
\cline { 2 - 7 } $\mathrm{L}$ & $>55$ & 10.55 & 0.63 & 0.45 & 0.316 & isg \\
$\mathrm{E}$ & & & & & & \\
\hline
\end{tabular}

Abbreviations used:

isg-insignificant

hsg-highly significant

\section{DISCUSSION:}

The average length of trachea found in this study was $10.4 \mathrm{~cm}$ in male and $9.6 \mathrm{~cm}$ in female respectively ( Fig:3, Table No.4 ) .The mean tracheal length found in this study were $9.85 \mathrm{~cm}$, $10.90 \mathrm{~cm}, 10.55 \mathrm{~cm}, 9.98 \mathrm{~cm}$. and $11.15 \mathrm{~cm}$ in males and 7.25 $\mathrm{cm}, 9.90 \mathrm{~cm}, 10.06 \mathrm{~cm}, 10 \mathrm{~cm}$ and $10.55 \mathrm{~cm}$ in females in the 0 15 years, $16-25$ years, $26-40$ years, $41-55$ years and $>55$ years age groups respectively ( Fig: 4, Table No.5 )

The $\mathrm{p}$ value was highly significant for tracheal length in 16-25 age groups and insignificant in rest age group in both sexes(Table:6).

Proctor, D.F (1997) ${ }^{6}$ stated that the distance between cricoids and the bifurcation of trachea is $12 \mathrm{~cm}$, while according to Engel $(1962)^{7}$, the average length of the trachea in adults was $9.15 \mathrm{~cm}$. According to Standring et al $(2005)^{1}$ it is $10-11 \mathrm{~cm}$ long.According to Cunningham's textbook of Anatomy ${ }^{8}$ the length of the trachea, is $7 \mathrm{~cm}$ between fourteenth and sixteenth year and $9-15 \mathrm{~cm}$ in adult.In the present study, the length did not exceed $11.2 \mathrm{~cm}$ in adults.

Guha et al (2010) ${ }^{4}$ conducted a study involving 87 specimens of human trachea and principal bronchi (51 male and 36 female) and noted the average length of trachea as $10.45 \mathrm{~cm}$ and $9.14 \mathrm{~cm}$ in male and female respectively. They also observedthat the length of the trachea increased from 0-15 years age group to 15- 25 years age group in both the sexes. Similar observation was made in the present study which is also in accordance with Croteau and Cook (1961) $)^{8}$ who stated that the tracheal length showed greater relative change in younger subjects this might be due to the fact that this period is the growing period of life.

They also stated that increase in height of the person has no correlation with the increase in tracheal length.

In the other group, that is from 26-40 years to $41-55$ years the increase or decrease of tracheal length was minimum. From 41-55 years to 55 years and $>55$ years there was a slight increase in tracheal length in both male and female, which might be due to the relaxation by more fibrous tissue present in this age group.

However, in a study carried out on 47 trachea of autopsied Bangladeshi adult male by Begum T et al (2009)9, the length of trachea increased with advancing age. In their study the average length of trachea in adult male was $9.42 \mathrm{~cm}$.

The results we observed were lower than those described by different western authors Shah $(2005)^{1}$, Snell(2004) ${ }^{10}$, Allen $(2003)^{11}$, Thibodean \& Patton $(2003)^{12}$, Sinnatamby (1999) $)^{13}$ and Ellis \& Feldman (1993) ${ }^{14}$. The geographical variation and racial differences may play a key role in results which may help our anasethesiologist, intensivist and clinician.

\section{CONCLUSION:}

The length of trachea, there was a rapid increase in length from 0-15 years group to 16-25 years group in both the sexes. Thereafter it exhibited very insignificant variations from 2640 and $41-55$ years group in both sexes. From $41-55$ years age group to $>55$ years age group there was a slight increase in tracheal length in both sexes.

To conclude, there is a wide variation in different components of human tracheo-bronchial tree in different age group in both sexes. Further more, an accurate anatomical knowledge of the same is of immense importance in problems of resection and reconstruction of the tracheobronchial tree as also in selecting proper size and gauge of endotracheal tubes and bronchoscopes respectively. 


\section{REFERENCES}

1. Shah P. Pleura, lungs, trachea and bronchi. In: Standring S, Ellis H, Healy JC, Williams A, editors. Gray's anatomy. 39thed. London: Elsevier Churchill Livingstone(2005). p.1075-8.

2. Hasleton PS, Curry A. Anatomy of the lung. In: Hasleton PS, editor. Spencer's pathology of the lung. 5th ed. New York: McGraw Hill (1996). p. 6-7.

3. Allen MS. Surgical anatomy of the trachea.Chest Surg Clin N Am $2003 ; 13: 191-9$

4. Guha R, Chunder R, Nandi S, Satyanarayana N. A morphometric study of human trachea and principal bronchi in different age groups in both sexes and its clinical implications. Nepal Med CollJ 2010 12(4):207-14.

5. Hasleton PS. Spencer's Pathology of the Lung. In Anatomy of the lung. Hasleton PS and Curry A (edrs). 5th edition. Vol.1.McGraw-Hill (1996): 6-7.

6. Proctor DF. The upper airways II. The larynx and trachea. Am Rev Respir Dis 1977 115(2):315-42.

7. Brock RC. The anatomy of the bronchial tree. 2nd edition. Oxford university press:London (1954).pp118-120.
8. Croteau JR, Cook CD. Volume-pressure and length-tension measurements in human trachea and bronchial segment. J Appl Physiol 1961;16:170-2.

9. Begum T, Naushaba H, Alam J, Paul UK, Alim AJ, Akter J, et al. Cadeveric length of trachea in Bangladeshi adult male. Bangladesh Journal of Anatomy 2009 7(1):42-4.

10. Snell RS. Clinical anatomy. 7th ed. Baltimore: Lippincott Williams and Wilkins(2004).p. 82.

11. Allen MS. Surgical anatomy of the trachea.Chest Surg Clin NAm 2003; 13: 191-9.

12. Thibodeau GA, Patton KT. Anatomy and physiology. 5th ed. St. Louis : Mosby, Inc (2003).p. 693-700.

13. Sinnatamby CS. Last's anatomy: regional and applied. 10th ed. Edinburgh: Churchill Livingstone(1999).p. 187-8.

14. Ellis H, Feldman S. Anatomy for anesthetists.6th ed. Oxford: Blackwell ScientificPublications, Inc(1993). p. 46, 51. 